\title{
A Case Who Has Smell - Color Synesthesia
}

\section{Kokuları Renk Olarak Algılayan Sinestezi Vakası}

\begin{abstract}
$\ddot{O z}$
Semih Erden ${ }^{1}$,

Halil Ozer²

Sinestezi, bir duyu modülünün uyarılmasıyla aynı veya farklı yöntem içerisinde istem dışı ek algılamalara neden olan bir durum olarak tanımlanır. Simdiye kadar yazı-renk, ses-renk, ses-hareket, ses-tat, renktat vb. olmak üzere 60 farklı sinestezi türü tespit edilmiştir. Sinestezi genel popülasyonda yaklaşık $\% 4$ olduğu tahmin edilmektedir. Yazı-renk ve ses-renk sinestezisi en yaygın formlarından biridir. Bu olgu sunumunda issitme-renk ve koku-renk sinestezileri olan, ilk duyusal deneyimleri altı yaşında başlayan ve şu an şikayetleridaha az olan bir olgudan bahsedilmiştir. Yapılan klinik değerlendirmede aktif bir psikiyatrik patoloji saptanmadı. Geçmiş öyküsü ve aile öyküsünde psikiyatrik bir patoloji yoktu. Olgumuzda nöbet ve travma öyküsü yoktu. Yapılan kranial MR ve EEG normaldi. Fonksiyonel MR görüntülemede sol serebralhemisferde daha çok aktivasyon sinyali izlenmiş olup sol serebralhemisfer dominanttı. Olgumuzun kardeşinde de benzer öykünün olması sinestezide genetik yatkınlığı düşündürmektedir.

Konya Training and Research Hospital,
Child and Adolescent Psychiatry Department, Konya, Turkey

${ }^{2}$ Gazi University Faculty of Medicine Department of Radiology, Ankara, Turkey
\end{abstract}

Anahtar Kelimeler: Sinestezi, koku-renk, ses-renk, sözcük-renk

Gelis Tarihi/Received: 30 March 2017

Kabul Tarihi/Accepted: 25 September 2017

\section{Abstract}

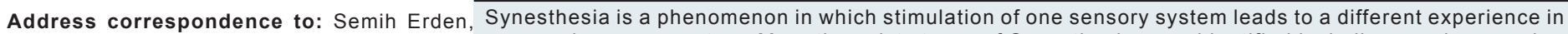

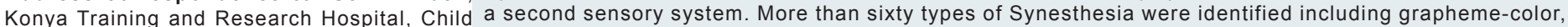

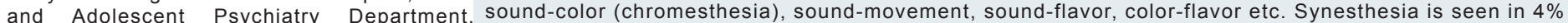
Konya, Turkey

e-mail: semihe84@gmail.com in general population. The grapheme-color and sound-color Synesthesia are the most common types. A case is discussed that has auditory-visual and smell-color types Synesthesia started at 6 year old but currently she has had fewer symptoms than before. An active psychiatric pathology is not found in clinical evaluation. There is neither significant patient history nor family history for psychiatric disorders other than a younger sister who has similar symptoms. She has not experienced any seizures or trauma. Her MRI and EEG were within normal limits. Functional MR imaging showed greater activation in the cerebral hemisphere that indicate lateralization. Since there is a positive familial history, we might consider genetic

ORCID

Semih Erden

https://orcid.org/0000-0002-7723-9584 predispositions.

Keywords: Synesthesia, odor-color, audio-color, lexical-color

\section{INTRODUCTION}

Synesthesia is described as a condition leading to involuntary additional perceptions in the same or different system when a sense module is stimulated (1). To a recent definition, synesthesia is a hereditary condition in which a triggering stimulant, or an automatic, involuntary, influenced and concious perception of a physical or cognitive feature different from the trigger arouses (2). In individuals with synesthesia, the simulation in sensory model usually activates additional perceptions related to another sensory model $(2,3)$. For example, a synesthete or an individual with synesthesia may report that red color may constitute the experience of taste (4). In this report, we aimed at evaluating a synaesthete with 17-year history of audio-color and odor-color synesthesia.

\section{CASE}

A23 year-old woman was admitted to our outpatient clinic with the complaint of difficulty falling asleep. Her detailed history revealed that the colorful graphemes of the words she had seen, heard and uttered were also visualized in her mind. It was found out that the case had been aware of these sensory experiences at the age of 6 and thought they were normal, but she sought medical assistance due to these challenges, and that no treatment regime was started. She reported that the the signs of the condition still continued, but the intensity in color tones were decreased, and that she saw the graphemes in a normal way where they were written but sensorially visualized and experienced the form of each grapheme in different color and font in her mind. For example, when she saw, heard or pronounced the term "happiness", the term was visualized and coded in her mind as "yellow" color. The case also stated that the color and graphemes of the names of objects showed no changes each time, but she sensorially experienced the names of friends with the same names in different colors and graphemes. For instance, when she uttered or heard the names of two friends called "Ayse", she sensorially experienced the name "Ayse" in her mind in different colors and fonts. She also pointed out that when any

Cite this article as: Erden S, Ozer H. A Case Who Has Smell - Color

Synesthesia. Selcuk Med J 2019;35(1): 55-57

Disclosure: None of the authors has a financial interest in any of the products, devices, or drugs mentioned in this article. The research was not sponsored by an outside organization. All authors have agreed to allow full access to th full access to the primary data and to allow the journal to review the data if requested. 
object was smelled, a color related to the object was experienced, and the object smelled in the color she experienced. As an example, the case described the smell of a perfume as lilac color. The case's brother also had a similar history. On clinical investigation, no active psychiatric pathology was determined in the case. Neither the case's nor familial history revealed any psychiatric pathology. Complete blood count and biochemical tests, and electroencephalography (EEG) were performed, and the results were found to be within normal limits. Cranial magnetic resonance imaging (MRI) demonstrated no pathology; however, on functional MRI (fMRI), activation signals were observed in left cerebral hemisphere at a higher rate, and left cerebral hemispheric dominance was present.

\section{DISCUSSION}

Synesthesia can be described as a sensorial experience in which an inducer stimulates an additional experience in the same or another sensory system (5). The incidence of synesthesia is estimated as $4 \%$ in general population (6). In another sudy, the frequency rate was reported to be nearly $1 \%$ in general public (7). Synesthesia can be divided into two main groups as constitutional (may be called as genuine) and acquired synesthesia (8). While the studies investigating acquired synesthesia are numerous, contitutional type of synesthesia is rarely seen, and its mechanism has been less understood $(4,7)$. Synesthetes were reported to maintain their routine and daily lives in a quite different way from typical individuals (8).

More than 60 different types of synesthesia, such as grapheme-color, sound-to-color, sound-kinetic, sound-flavor or color-flavor, have been determined so far $(9,10)$. An inducer can concurrently stimulate multiple perceptions; for instance, a grapheme can concurrently produce a different color or flavor perception (2). Grapheme-color and sound-color types of synesthesia are among the most common

forms $(4,7,8)$. In grapheme-color synesthesia, acromatic letters or numbers trigger secondary color experiences. In our case, audio and visual words were experienced as graphemes in different colors and fonts.

In a report, the case with Asperger's syndrome was stated to label the emotions with colors (e.g. feeling green color when s/he was happy) and to succeed in reading accurately the respondent's feeling by matching the respondent's color with the one in his or her own mind (11). Our case displayed no sensorial experience due to her emotional state, but experienced the same names of two different friends sensorially in different colors. In addition, our case also announced to experience the name of any friend sensorially in the same color at different times. Such a condition suggests that emotions and mutual relationships may have effects on sensorial experiences. It was demonstrated that synesthesia could stem from temporal lobe, and especially develop in temporal lobe epilepsy and lesions $(3,4)$. On EEG investigations, increased activity responses were demonstrated to visual stumuli in primary visual cortex in synesthesic events (12). Our case reported no history of clinical seizures; on EEG investigation, no ephileptiform anormalies were detected; the findings of cranial MRI were within normal limits; on fMRI, more activation signals were observed in left cerebral hemisphere, and left cerebral hemisphere was dominant. The data obtained from an fMRI study investigating the effect of synesthesia on early visual cortex activation demonstrate that sensorial proceedings of the stimuli inducing synesthesia differ for both perceptional and memory tasks (12). The presence of similar sensorial experiences in our case's brother also suggests hereditary propensity in synesthesia. In a study, it was reported that sound-vision synesthesia is an oliogenic disorder probably related to multiple hereditary and locus heterogenity. The same study also found no significant association in terms of the transmission of synesthesia via chromosome $X$ (13). In another study, synesthesia was suggested to be a hereditary condition with incomplete penetrance significantly affected by epigenetic and environmental factors (14). Neurophysiologic mechanism of synesthesia still remains unclear on a large scale. There are three effective hypotheses referring to the underlying mechanisms of synesthesia: cross activation, cortical disinhibition and disinhibited feedback theory $(7,15)$. However, another hypothesis is related to the detachment of cross neuronal pathways during the neurodevelopmental period (4). Despite several theories aiming at referring to its mechanisms, certain pathophysiology of synesthesia still remains unclear. In literature, two cases reporting that synesthesia is inhibited by fluocsiety, and a case indicating that bupropion stops synesthesia temporarily have been reported; even so, a thorough treatment regime is yet to be proposed (16). Since there is a positive familial history, we thought that genetic predispositions can be the one of the causes of synesthesia. 
Conflict of interest: Authors declare that there is no conflict of interest between the authors of the article.

Financial conflict of interest: Authors declare that they did not receive any financial support in this study.

Address correspondence to: Semih Erden, Konya Training and Research Hospital, Child and Adolescent Psychiatry Department, Turkey Postal code:42000 Meram/Konya/Turkey

e- mail: semihe84@gmail.com Phone: +90 5368526129

\section{REFERENCES}

1. Robertson LC, Sagiv N. Synesthesia: Perspectives from cognitive neuroscience: Oxford University Press;2004.

2. Cytowic RE, Eagleman D. Wednesday is indigo blue: Discovering the brain of synesthesia: MIT Press;2009.

3. Cytowic RE. Synesthesia: A union of the senses: MIT press;2002.

4. Afra P, Funke M, Matsuo F. Acquired auditory-visual synesthesia: A window to early cross-modal sensory interactions. Psychology research and behavior management 2009;2:31-7.

5. Grossenbacher PG, Lovelace CT. Mechanisms of synesthesia: Cognitive and physiological constraints. Trends Cogn Sci 2001;5(1):36-41.

6. Simner J, Mulvenna C, Sagiv N, et al. Synaesthesia: The prevalence of atypical cross-modal experiences. Perception 2006;35(8):1024-33.
7. Kadosh RC, Walsh V. Synaesthesia and cortical connections: Cause or correlation? Trends Neurosci 2008;31(11):549-50.

8. Ward J. Synesthesia. Annual review of psychology 2013;64:49-75.

9. Banissy MJ, Jonas C, Kadosh RC. Synesthesia: An introduction. Front Psychol 2015;11:5.

10. Ward J, Simner J. Lexical-gustatory synaesthesia: Linguistic and conceptual factors. Cognition 2003;89(3):237-61.

11. Ramachandran VS, Miller L, Livingstone MS, et al. Colored halos around faces and emotion-evoked colors: A new form of synesthesia. Neurocase 2012;18(4):352-8.

12. Pfeifer G, Ward J, Chan D, et al. Representational account of memory: Insights from aging and synesthesia. J Cogn Neurosci 2016;28(12):1987-2002.

13. Asher JE, Lamb JA, Brocklebank D, et al. A whole-genome scan and fine-mapping linkage study of auditory-visual synesthesia reveals evidence of linkage to chromosomes 2q24, 5q33, 6p12, and 12p12. Am J Hum Genet 2009;84(2):279-85.

14. Bosley HG, Eagleman DM. Synesthesia in twins: Incomplete concordance in monozygotes suggests extragenic factors. Behav Brain Res 2015;286:93-6.

15. Ramachandran VS, Hubbard EM. Synaesthesia- A window into perception, thought and language. J Consci Stud 2001;8(12):3-34.

16. Brang D, Ramachandran VS. Psychopharmacology of synesthesia; the role of serotonin s2a receptor activation. Med Hypotheses 2008;70(4):903-4. 